\title{
Evaluating profit organizations' financial tools development strategy for managing crises
}

\author{
Abdullah Ibrahim Nazal \\ Zarqa University, Jordan. \\ Accepted 14 October, 2013
}

\begin{abstract}
The purpose of the study is to evaluate profit organizations' financial tools development strategy in order to find limits. These limits can help the strategy to organize development internationally and locally without solving crises with negative effect. The study found out that there were negative outcomes because profit organizations were ignorant of their responsibility and were revenue oriented without considering the balance between their aims and that of their countries. This leads to weak monetary and financial policies. Islamic profit companies (as a case study) avoid interest with bad effects, being ignorant of one's responsibility and negative effects on countries' aims, by applying fixed and flexibility rules. Limits can speculate dealing and stages of financial tools life cycle. But this is not enough; there must be fixed and flexibility rules decided by law in addition to rules that control economic sectors for protection of communities. It is suggested that development be controlled up by contract conditions, which must be practical as Islamic companies share their account.
\end{abstract}

Key words: Crises, profitable organizations, developing financial tools, limits.

\section{INTRODUCTION}

\section{Background}

Budget management gives idea about change of economic. Financial managers must try to understand the economic framework and be alert about the consequences of varying levels of economic activity and changes in economic policy; they must also use economic theories as guidelines for efficient business operation. Financial decisions should be made and actions taken only if there would be added benefits that exceed the added cost (Lawrence, 2000). Profit organizations aim to make great net profit even in limited time or to increase their assets value. Some organizations can make their sales in other counties to avoid sales tax, increase their sales price or reduce currency risks. When producing goods, costs need to be decreased. There may be increase in price of inter goods during production. Developing financial tools gives way to keep inter goods price in suitable price. Rather than storing entering goods, options or future contracts can be made to reduce cost. The problems come in two ways: first, options or future contract give right to make deal in future, but there will be no deal at the time of making the contract. Second, there is speculation on these rights without owning goods. Selling one's rights to another leads to ignorance.

\section{The problem}

The problem is profit organizations want to achieve revenue as much as possible within a limited time by developing financial tools strategy. This strategy can be affected by the monetary policy or financial policy of the country on its possible revenue. Rapid development is more than covering rules. This problem can be cleared by these questions:

1. Can profit organizations' financial tools development 
strategy (with negative and positive effects) be evaluated at suitable time ?

2. Can profit organizations' negative effects be limited and their positive effects increased?

3. How can we manage profit organizations' economic crises up to standards and practically control their account?

\section{The importance}

At this time, it is important to find the problems of developing financial tools which culminate to crises. This study discusses standards for achieving three aims which are social responsibility, aims of financial policy and monetary policy in order to limit negative effects and direct development to make crises have positive effects. It helps to balance the aims of profit organization and social responsibility, financial policy aims and monetary policy in the country. Also it shows the ways of balancing profit organizations with their countries' aims or to avoid bad effects by creating standards and controlling account

\section{Objectives}

The main objectives of this paper are,

1. To find positive effect of developing financial tools.

2. To find negative effect of developing financial tools.

3. To limit developing financial tools effects in order to increase positive effects and reduce negative effects as a way to solve crises.

\section{PREVIOUS STUDIES}

Pedro and Erwan (2010) show that there is a strong statistical relationship between financial development and economic development. This is often presented as evidence that financial development causes economic development by promoting investment and making allocation of resources more efficient (Thomas, 2011).

Center bank decides that monetary policy must agree on assets development or improvement in banks because it is important to save in own country than migrating to other countries. Jean et al. (2011) cleared the relation between company's decision and financial policy. As private companies decide their cash holding policies and dividend payment up to market expectation, if countries increase their expectation, if countries increase their expenses amount as aids to people, this would encourage companies to get payments in cash more quickly.

Some other studies concentrated on the importance of social responsibility; like Mc Kinsey (2010) who found that corporate social responsibility contributes positively to long term shareholders' value and helps their companies to build strong reputation. Chatterji et al. (2009) found out that poor social responsibility leads to sell outs of companies' shares by large investment fund which decreases companies' financial performance. David (2012) studied the effect of investors' relations and firm's news on stock prices. It affects returns and media coverage. Nastlin et al. (2006) found that retaining customer is key drive of profit. So he recommended that it is important for profit firms to build predictive model for customers' real needs.

On the other hand, some studies showed conflict between some countries' aims and their companies' aims. Other studies concentrated on solving deficit problems affecting citizens; an example is Ahmed (2003). He aims to analyze general budget by correcting economic policy. $\mathrm{He}$ found that reducing of current economic policy, current expenses, obligating price on essential products produced by local company and increasing tax besides encouraging foreign companies were not successful. It makes local companies weak and increases deficit. There were many studies that tried to apply Islamic economic rules to avoid negative effect of developing financial tools; like Ahmed (1998) who aims to study budget deficit in order to find solution. From his result, Ahmad suggested integration with other countries and using solutions from Islamic economic system as rules to organize companies' aims and countries' policies.

\section{POSITIVE AND NEGATIVE EFFECTS OF PROFIT ORGANIZION'S FINANCIAL TOOLS DEVELOPMENT STRATEGY}

Studies of Holzach (1985) and David (1985) encourage that developing financial tools should concentrate on banks. They may develop their services which relate to financing or investing by improving steps of services, producing some services as one or making new service (Midan, 1988). Developing or improving products has advantages; it is just like increasing quality to make it similar to competitors' product or solving clients' problems; it could involve giving unique benefit to client or establishing standards better than that of other competitors. As profit organizations work in open environment their financial tools face changes. Life cycle stages show tools pricing with their risks (Zeithaml and Bitner, 2000) (Table 1).

Profit organizations use resources to produce products. If there is increase in tax in their country, profit organizations would face this by many ways. They include reducing workers, leaving the country or developing financial tools to make cost suitable. These solutions will affect the country negatively. Reducing worker will decrease workers' income and increase country's expenses to help these workers. Leaving the country 
Table 1. Asset lifecycle stage and banks strategy.

\begin{tabular}{ll}
\hline Asset lifecycle stages & Banks' strategy \\
\hline $\begin{array}{l}\text { Introducing stage } \\
\text { market }\end{array}$ & $\begin{array}{l}\text { Expansionism: it will produce new asset if there is possible needs in } \\
\text { enough resources, competition and possibility to reduce cost. }\end{array}$ \\
Growth stage & $\begin{array}{l}\text { Permeation: it will promote the advantages of the assets to keep growth } \\
\text { of profit . }\end{array}$ \\
Maturity stage & $\begin{array}{l}\text { Defense : improving assets to keep profit } \\
\text { Fall stage }\end{array}$ \\
\hline
\end{tabular}

Table 2. Effects of profitability organization developing financial tools to finance their asset.

\begin{tabular}{|c|c|c|}
\hline & Negative effect & Positive effect \\
\hline Selling bonds & $\begin{array}{l}\text { Possibility of transferring rights of loan interest to } \\
\text { competitors } \\
\text { Affected by negative speculation. } \\
\text { Financial marking rules not allowing the organization to } \\
\text { sell bonds. }\end{array}$ & $\begin{array}{l}\text { Any unusual return will be owned by } \\
\text { the organization }\end{array}$ \\
\hline Banks & $\begin{array}{l}\text { Possibility of transferring rights of loan and interest to } \\
\text { competitors. } \\
\text { Affected by negative speculation. } \\
\text { Affected by increasing cost due to changing of interest. } \\
\text { Bank rules not allowing the organization to get loan }\end{array}$ & $\begin{array}{l}\text { Any unusual return will be owned by } \\
\text { the organization }\end{array}$ \\
\hline $\begin{array}{l}\text { Sharing with other } \\
\text { shareholders }\end{array}$ & Any unusual return is shared with shareholders & $\begin{array}{l}\text { Any loss will be shared with } \\
\text { shareholders }\end{array}$ \\
\hline Buying on credit & $\begin{array}{l}\text { Possibility of transferring rights of loan and interest to } \\
\text { competitors } \\
\text { Companies rules against buying on credit }\end{array}$ & $\begin{array}{l}\text { Any unusual return will be owned by } \\
\text { the organization }\end{array}$ \\
\hline
\end{tabular}

makes the country lose its tax returns. Derivatives have two sides: it can reduce cost and can lead to ignorance especially in speculation. It may give high price just because of speculation demand for future expectation. This means losing investment and savings. By developing financial tools, profit organizations finance their assets. They can finance their needs by sharing with other shareholders or buy on credit from other companies. Every way has positive and negative effect (Table 2). As selling of debts is possible, there is way to make unusual return because of speculation. Demands can be increased by increasing bound return or guarantee or increasing of bond currency price. Financial tools can control expected risk. Mortgage crisis, as an example, is profit. It can increase profit by developing loan contract to be bond. This increases flexibility to get liquidity and makes other profits by speculation. Speculation demand can be increased to get other profits by increasing the international credit rating up to grantees. other profits can be got by increasing asset evaluation which is financed by loan. Bonds mortgage price can be changed to interest rate, assets price and grantee value. These lead to ignorance. Fast dealing and amount of demand increase expected profit until bonds' real value is to lose mortgage to buy in debts.

\section{LIMITS OF ACCEPTING DEVELOPING FINANCIAL TOOLS}

Limit is important to control and direct developing financial tools. Profit organizations have ability to improve or develop financial tools to meet their aims. But due to its negative effect on countries, developing financial tools have to be controlled by law. This is important to make direct investment in different economic sectors successful. As development has positive effect, a country can direct it to solve economic or financial crises. It can use developing financial tools as tools for its monetary policy or financial policy. It can also use limits to control or direct development. There are limits to increase the advantages of developing financial tools and reducing disadvantages. 
It is important to relate profit organizations to growth of economic sector and counties' organizations' loss could lead to bad relation between countries. There are many limits to complex environment. Using one of the developing financial tools means there are legal duties and rights that must be done in any contract. Steps and procedures of contract must be made clear to dealers for them to know the rights or duties to apply. Contract can be done manually or by machines such as using internet. Buying bonds from financial market shows the importance of knowing the steps of buying and legal way to manage risk. This helps to turn sellers' duties to buyer's debts and interest in future. Every profit organization has resources, life cycle and products life customers' need, it faces the problems of making profit and having the ability to indulge in competition.

\section{Case study: Evaluating profit organizations' financial tools development strategy to manage stocks speculations crises by Islamic companies}

Stocks speculations crises come as a result of ignorance, interest and loss of responsibility. Ignorance leads to increased speculation crises because of gambling with the possibility of future increasing or decreasing price. There must be interest on debts even if a company makes loss. Some gaps in law lead to the problem of losing responsibility, which makes transfer of duties an option. Option like buying of shares with limited price to avoid increasing price in the future gives dealers the right to continue with or cancel the contract. Also, options of contract can be selling of right regardless of the owners of the shares. These things lead to unstable standard used in dealings (Abdullah, 2006). Common shares in Islamic economic have rules. Therefore, Islamic profit companies apply company's law of the country but with neglecting any Islamic rule. It does not establish what if the company's law goes against the Islamic rules. Its common shares mean sharing in investment. Selling common shares means sharing in a company's investment. It may be involved in managing share like moushraka or not managing like Modaraba. Also if it shares by Moushraka, then it will be for long term known as permanent Moushraka or for short term called decreesing Moushraka. This means Islamic companies can sell common shares for long and short terms due to the possibility of buying theses shares in limited time. Inspite of the similarity among traditional stock companies, the difference come as a result of Islamic rules which are as follows.

\section{First: Effect of fixed rules}

1. Shareholders must not sell their common shares more than par value until liquidation of capital change from cash to other assets. It is a way to protect currency value by avoiding creation of money

2. Managers can get wages but not part of net profit or can get just part of net profit, but for other shareholders who manage share they must take part of net profit. It is a way of protecting almost all shares by ordering the manager to do his best or not get revenue.

3. Any amount of net profit got by a company would be one of the rights of shareholders. This means undistributed profit must be given to shareholders.

Therefore, every equity items are owned by shareholders making them to deserve part of the net profit.

1. Loss must be divided among all shareholders but not the amount of shares. This makes loss to be distributed among all sharers.

2. Net profit is distributed by the percentage the shareholders agree on. It takes sharers with different abilities to manage it.

3. Percentage of net profit distribution is decided during the signing of the contract of selling common shares. It prevents ignorance which may lead to problems.

4. Shareholders have the right to get revenue due to increasing value of net profit and asset up to market price regardless of historical value.

5. Interest is prohibited because of its negative effects. Example: suppose a company has common 300,000 shares and its value is up to net profit and market assets value; and other revenues are equal to $\$ 3,000,000$. In order to finance new assets, it decides to sell new common shares of 300,000 to get $\$ 3,000,000$. Every share will get $30 \%$ of revenue. Distribution of revenue will be as follows:

First: if the sharing is not limited by time (Permanent Moushraka) (Table 3).

Second: if the sharing is limited by time (Decreasing Moushraka):

Example: suppose a company sells common shares as decreasing Moushraka in a limited time. This means to buy new common shares from old shareholder's revenue. This has to be the buying of $80 \%$ of old shareholders' revenue $($ Table 3,4$)$.

This means old shareholders had owned all capital after two years.

Third: If the sharing was limited by time and was lost (Table 5).

New shareholders will lose from their capital :

(New shareholders' capital/ all capital) x Loss $(1.640,000$

$/ 6,000,000)=819,999.9 \times 3,000,000$

Therefore, their capital becomes 820,000

Old shareholders will lose their capital: (new shareholders' capital/all capital) x Loss $(4,360,000 / 6,000,000)$ $=x 3,000,000$

Therefore, their capital becomes 2,180,000.

This mean rules may come from companies managing 
Table 3. Permanent Moushraka calculated revenue.

\begin{tabular}{ccccccc}
\hline Year & $\begin{array}{c}\text { All } \\
\text { capital } \\
\text { price }\end{array}$ & $\begin{array}{c}\text { Capital of old } \\
\text { shareholders }\end{array}$ & $\begin{array}{c}\text { Capital of new } \\
\text { shareholders }\end{array}$ & $\begin{array}{c}\text { Yearly revenue as profit } \\
\text { and assets market } \\
\text { increasing }\end{array}$ & $\begin{array}{c}\text { Revenue for } \\
\text { new } \\
\text { shareholders }\end{array}$ & $\begin{array}{c}\text { Revenue for } \\
\text { old } \\
\text { shareholders }\end{array}$ \\
\hline & & & & & $30 \%$ & $70 \%$ \\
2010 & $6,000,000$ & $3,000,000$ & $3,000,000$ & $1,000,000$ & 300,000 & 700,000 \\
2011 & $6,000,000$ & $3,000,000$ & $3,000,000$ & 500,000 & 150,000 & 350,000 \\
2012 & $6,000,000$ & $3,000,000$ & $3,000,000$ & 600,000 & 180,000 & 420,000 \\
\hline
\end{tabular}

Table 4. Decreasing Moushraka calculated in case of no loss.

\begin{tabular}{|c|c|c|c|c|c|c|c|}
\hline Years & $\begin{array}{c}\text { All } \\
\text { capital }\end{array}$ & $\begin{array}{c}\text { Capital of } \\
\text { old } \\
\text { shareholders }\end{array}$ & $\begin{array}{c}\text { Capital of } \\
\text { new } \\
\text { shareholders } \\
\end{array}$ & $\begin{array}{c}\text { Yearly revenue as profit } \\
\text { and assets market price } \\
\text { increase }\end{array}$ & $\begin{array}{c}\text { Revenue for new } \\
\text { shareholders } \\
(30 \% \times \text { revenue }) \\
\end{array}$ & $\begin{array}{l}\text { Revenue for old } \\
\text { shareholders } \\
70 \% \times \text { revenue } \\
\end{array}$ & $\begin{array}{l}\text { Old shareholders' revenue } \\
(80 \%)\end{array}$ \\
\hline \multirow[t]{2}{*}{2010} & $6,000,000$ & $3,000,000$ & $3,000,000$ & $4,000,000$ & $1,200,000$ & $1,700,0$ & $\begin{array}{l}1,360,000 \text { taken from new } \\
\text { shareholders' capital and } \\
\text { added to old shareholders' } \\
\text { capital }\end{array}$ \\
\hline & & & & & & & $\begin{array}{l}1,680,000 \text { taken from new } \\
\text { shareholders' capital and } \\
\text { added to old shareholders' } \\
\text { capital as it will be more than }\end{array}$ \\
\hline 2011 & $6,000,000$ & $4,360,000$ & $1,640,000$ & $3,000,000$ & 900,000 & $2,100,000$ & $\begin{array}{l}1,640,000 \text { is the right of new } \\
\text { shareholders and old } \\
\text { shareholders just buy } \\
1,640,000 \text { to own all capital }\end{array}$ \\
\hline 2012 & $6,000,000$ & $6,000,000$ & zero & $6,000,000$ & zero & $6,000,000$ & zero \\
\hline
\end{tabular}

them. Practically, these rules will direct managing them. Practically, these rules will direct management of/and accounting for profit.

\section{Conclusion}

The study showed that the problem came as a result of profit organization developing financial tools strategy to maximize profit in open environment regardless of the community's rights and country's aims. Negative effect came as a result of ignorance of responsibility. This leads to weak monetary policy and financial policy. There is a way to increase the strategy advantage of organizations and reduce their disadvantages through limits. Limits can be used to decide speculation dealing and stage of financial tools of life cycle. But this is not enough. There must be law. Islamic profit companies as case study avoid bad effects of interest, responsibility ignorance and negative effect on country's aims by applying fixed and flexibility rules. Practically, Islamic profit companies apply these limits to sell their common shares. These limits have directed their accounting revenue, making it possible to control balance between all aims, practically. 
Table 5. Decreasing Moushraka calculated revenue when there is loss.

\begin{tabular}{|c|c|c|c|c|c|c|c|}
\hline Years & $\begin{array}{c}\text { All } \\
\text { capital }\end{array}$ & $\begin{array}{l}\text { Capital of } \\
\text { old } \\
\text { shareholders }\end{array}$ & $\begin{array}{c}\text { Capital of } \\
\text { new } \\
\text { shareholders }\end{array}$ & $\begin{array}{l}\text { Yearly revenue as profit and } \\
\text { assets market price increase }\end{array}$ & $\begin{array}{c}\text { Revenue for new } \\
\text { shareholders ( } 30 \% \text { x } \\
\text { revenue) }\end{array}$ & $\begin{array}{l}\text { Revenue for old } \\
\text { shareholders } \\
70 \% \times \text { revenue }\end{array}$ & $\begin{array}{l}\text { Old shareholders' } \\
\text { revenue }(80 \%)\end{array}$ \\
\hline 2010 & $6,000,000$ & $3,000,000$ & $3,000,000$ & $4,000,000$ & $1,200,000$ & $1,700,0$ & $\begin{array}{l}1,360,000 \text { taken from } \\
\text { new shareholders' capital } \\
\text { and added to old } \\
\text { shareholders' capital }\end{array}$ \\
\hline 2011 & $6,000,000$ & $4,360,000$ & $1,640,000$ & $\begin{array}{l}(-3,000,000) \text { Losing dividend } \\
\text { sharing in capital not as agreed } \\
\text { between shareholders }\end{array}$ & zero & zero & zero \\
\hline 2012 & $3,000,000$ & $2,180,000$ & 820,000 & $6,000,000$ & $1,800,000$ & $4,200,000$ & 820,000 \\
\hline 2013 & $3,000,000$ & $3,000,000$ & zero & & & & \\
\hline
\end{tabular}

\section{RECOMMENDATION}

The researcher recommended the studying of effect of financial tools using Islamic profit companies as a case study. Then limits should be made to avoid deflection between organizations with legal aims using strategy of profit organizations. This will lead to economic growth. This can be applied in accounting revenue either through net profit or by increasing assets. The researcher suggests model for controlling developing financial tools used in contract dealing with the following questions:

1. What are the fixed rules of contract that cannot be changed in developing financial tool? This will make contract legal and determine the rights and duties needed in any kind of contract in any environment.

2. What are the flexibility rules used to develop contract either by adding or reducing environmental risk conditions if the fixed rules of contract accept these conditions? This will make possible adjustment on the contract if the conditions are

\section{accepted.}

3. What are the rules that control economic sectors for the protection of any community? This will give any country the ability to develop its financial tools in order to help its monetary policy or financial policy.

\section{REFERENCES}

Ahmed M (2003). Analyses study about general budget in Jordan up to economic correctly policy. U.A.E, Union chamber of industry and commercial, Econ. Horizons. J. 24(94):94-97.

Ahmed Y (1998). Solving general budget deficit between modern opinion and Islamic opinion: comparative study. Kingdom of Saudi Arabia. Publ. Manage. J. 38(1):175-213.

Chatterji A, David L, Micheal WT (2009). How well do social ratings Actually Measure corporate Social Responsibility? Wiley Periodicals Inc, J. Econ. Manage. Strat. 18(1):165

David HS (2012). Selective Publicity and stock Prices. The American Finance Association, U.S.A. J. Finan. 67(2):599.

Jean-Paul D, Thomas M, Jean CR, Stephane V (2011). The American finance Association Free cash flow, Issuance Costs and Stock Prices, U.S.A. J. Finan. 66(5):1533.

Lawrence JG (2000). Principles of Managerial Finance. ninth edition. Addisson Wesley Publishing Company, U.S.A Chapter 5. Chapter 16 chapter 17 and p.10.
Midan A (1988). Bank Marketing Management, 2ND Edition, Machmillan Education LTD. London, England pp.99-101.

Pedro SA, Erwan Q (2010). Limited Enforcement, Financial Intermediation, and Economic development: A Quantitative Assessment, International Economic Review, Economic Department of University of Pennsylvania and the Osaka University Institute Soc, U.S.A, Econ. Res. Assoc. 51(3):785

Thomas $\mathrm{H}$, Zieseme $\mathrm{W}$ (2011). Saving finance emigration and worker remittances serve to make staying rather than migrating possible, UK, Int. Econ. J. 25(3):373.

Zeithaml VA, Bitner MJ (2000). Services Marketing International Customer Focus Across the Firm, Second Edition, McGraw-Hill Companies, Inc, U.S.A, p.198. 